\title{
Opioids are non-competitive inhibitors of nitric oxide synthase in T47D human breast cancer cells
}

\author{
M Kampa ${ }^{1}$, A Hatzoglou ${ }^{1}$, G Notas ${ }^{2}$, M Niniraki ${ }^{3}$, \\ $E_{\text {Kouroumalis }}^{2}$ and $E$ Castanas $^{\star, 1,3}$ \\ ${ }^{1}$ Laboratory of Experimental Endocrinology, University of Crete, School of \\ Medicine, and University Hospital, PO Box 1393, Heraklion, GR-71110, Greece \\ ${ }^{2}$ Laboratory of Gastroenterology, University of Crete, School of Medicine, and \\ University Hospital, PO Box 1393, Heraklion, GR-71110, Greece \\ 3 Laboratory of Immunology, University of Crete, School of Medicine, and \\ University Hospital, PO Box 1393, Heraklion, GR-71110, Greece \\ * Corresponding author: Dr E Castanas, Laboratory of Experimental \\ Endocrinology, University of Crete, School of Medicine, P0 Box 1393, \\ Heraklion, GR-71110, Greece. Tel: +3081 394580, Fax: +3081 394581; \\ E-mail: castanas@med.uoc.gr
}

Received 8.9.00; revised 9.4.01; accepted 18.4.01 Edited by G Melino

\begin{abstract}
Opioids and nitric oxide (NO) interact functionally in different systems. NO-generating agents decrease the activity of opioid agonists, prevent opioid tolerance, and are used in opioid withdrawal syndromes. There exist, however, few reports indicating a direct interaction of the two systems. T47D human breast cancer cells in culture express opioid receptors, and opioid agonists inhibit their growth, while they release high amounts of the NO-related molecules $\mathrm{NO}_{2}{ }^{-} / \mathrm{NO}_{3}{ }^{-}$to the culture medium. We have used this system to assay a possible direct interaction of opiergic and nitric oxide systems. Our results show that $\delta$ - or $\mu$-acting opioid agonists do not modify the release of $\mathrm{NO}_{2}{ }^{-} \mathrm{I}$ $\mathrm{NO}_{3}{ }^{-}$. In contrast, $k$-acting opioid agonists (ethylketocyclazocine, and $\alpha_{\mathbf{s}_{1}}$-casomorphine) decrease the release of $\mathrm{NO}_{2}{ }^{-} / \mathrm{NO}_{3}{ }^{-}$, in a time- and dose-dependent manner. The general opioid antagonist diprenorphine $\left(10^{-6} \mathrm{M}\right)$ produce a similar $\mathrm{NO}_{2}{ }^{-} / \mathrm{NO}_{3}{ }^{-}$release inhibition, indicating a possible non-opioid-receptor mediated phenomenon. In addition,

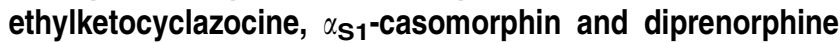
directly inhibit NOS activity: agonists, interact with both calcium-dependent and independent NOS-isoforms, while the antagonist diprenorphine modifies only the activity of the calcium-dependent fraction of the enzyme. Analysis of this interaction revealed that opioids modify the dimeric active form of NOS, through binding to the reductase part of the molecule, acting as non-competitive inhibitors of the enzyme. This interaction opens interesting new possibilities for tumor biology and breast cancer therapy. Cell Death and Differentiation (2001) 8, 943-952.
\end{abstract}

Keywords: nitric oxide; opioids; breast cancer
Abbreviations: EKC, ethylketocyclazocine; DSLET, [D-Ser ${ }^{2}$ Leu $^{5}$ ]-enkephalin-Thr ${ }^{6}$; DAGO, [D-Ala ${ }^{2}, \mathrm{~N}-\mathrm{Me}-\mathrm{Phe}^{4}$, Gly ${ }^{5}$-ol]enkephalin; NO, nitric oxide; NOS, nitric oxide synthase; PMA, phorbol 12-myristate, 13-acetate

\section{Introduction}

Opioids were found to derive, in all animal species, from three major propeptides (proenkephalin A and B and proopiomelanocortin) and to bind in three major classes of opioid receptors $(\delta, \mu$ and $\kappa)$ (see ${ }^{1}$ for a recent review). Pharmacological evidences further indicate that multiple subtypes of each opioid receptor might exist (at least two for the $\delta$, two for the $\mu$ and three for the $\kappa$ opioid receptor). In addition to the classical opioid peptides Met $^{5}$ - and Leu ${ }^{5}$-enkephalin, beta-endorphin, dynorphins) a number of opioid peptides, derived from the limited proteolysis of endogenous or food proteins, were identified, including casomorphins, derived from $\alpha$ - and $\beta$ caseins of animal and human origin (see ${ }^{2}$ for a review). Recently, we have identified an opioid sequence from $\alpha_{\mathrm{S} 1^{-}}$. casein, named alpha ${ }_{\mathrm{S}_{1}}$-casomorphin, with a kappa-opioid receptor activity, which is very potent in inhibiting cell proliferation of a number of different cancer cell lines, in vitro. $^{2-5}$ In addition, a number of synthetic peptide analogs were reported as selective agonists of delta (DSLET), or mu (DAGO) opioid receptors. These peptides possess a greater stability to endo- and exopeptidases found in the receptor environment. ${ }^{6}$

Nitric oxide (NO) is a gaseous molecule. It is produced through the enzymatic deamination of arginin to citrulline, by the enzyme nitric oxide synthase (NOS). Nitric oxide synthase exists in three different isoforms in mammalian species: eNOS, membrane bound, nNOS bound to different cellular membrane elements, and the cytosolic iNOS. These three isoforms have different molecular masses (135, 150 and $130 \mathrm{kD}$ respectively) and are products of different genes. ${ }^{7,8}$ Calcium is necessary for the action of some forms of the enzyme, although no clear-cut distinction of the molecular form and calcium-dependency can be made. During the last decade, NO has been recognized as an important messenger molecule in mammalian species. It acts through modification of soluble guanylate cyclase activity $^{9}$ and cGMP intracellular levels. Nitric oxide is an important regulator of different functions, including vasodilation and neurotransmission, although high concentrations of this agent could be either beneficial (anti-bacterial, antiparasitic or anti-viral) or detrimential, inducing cell death. ${ }^{10}$ The mechanism of this dual action includes a sophisticated regulation of nucleat transcription factors, and regulation of a number of intracellular proteins. ${ }^{10}$ The role of $\mathrm{NO}$ in cancer is also contradictory. Nitric oxide could oxidize nucleic acids and induce DNA damage, although it can 
enhance the tumoricidal activity of the immune system. In addition, NO production by tumor cells could enhance the angiogenetic and metastatic potential of tumors (see ${ }^{11}$ for a review).

A functional interaction between opiergic and nitric oxide (NO) systems in different organs has been reported so far. NO-related agents inhibit morphine action on testicular steroidogenesis, while nitric oxide synthase inhibitors reverse the action of opioid antagonists, ${ }^{12}$ through separate intracellular pathways. ${ }^{13}$ In addition, NO or arginin (a NO precursor) decrease the potency of morphine ${ }^{14-16}$ through a modulation of intracellular concentrations of cGMP, without modifying the characteristics of opioid binding. ${ }^{17,18} \mathrm{NO}$ reverts the opioid-exerted inhibition on $\mathrm{LHRH}^{19-21}$ and $\mathrm{GnRH} / \mathrm{CRH}$ secretion. $^{22}$ In contrast, a direct stimulation of $\mathrm{NO}$ secretion at the cardiac atrium by morphine was reported, ${ }^{23}$ while, in the vascular endothelium, a $\mu$-opioid receptor was identified, acting, at least partially, through a functional coupling with c- and iNOS. ${ }^{24-28}$

NO-releasing agents can prevent $\mu$ receptor-mediated opioid tolerance but not dependence, ${ }^{16,29-33}$ and they have been used experimentally for the treatment of opioid withdrawal syndromes, ${ }^{34-42}$ while NOS inhibitors enhance the antinociceptive effects of opioids. ${ }^{43,44}$ In opioid dependence, increased nNOS immunoreactivity was found. ${ }^{45}$ Furthermore, after Met $^{5}$-enkephalin application in rat brain synaptosomes, an increase of membrane fluidity, $\mathrm{NO}$ and cGMP production, were observed. ${ }^{46}$ The activation of NOS-cGMP pathway was proposed as the underlying mechanism for morphine-induced antinociception, ${ }^{47-49}$ through two distinct isotypes of nNOS. ${ }^{50}$ Mu-opioid receptors and nNOS were co-localized in the rat's nervous system. ${ }^{51}$ In the canine gut, NOS inhibition decreased or abolished the action of $\mu$ - and $\delta$-opioid agonists. ${ }^{52}$ Finally, nociceptin was reported to act through an inhibition of tonic NO secretion. ${ }^{53}$

Previous works have shown that the proliferation of T47D human breast cancer cells is inhibited, in a dosedependent and reversible manner, by opioid agonists, through an interaction with $\delta$ - and $\kappa$-opioid receptors. ${ }^{2,54-56}$ In addition, these cells show a very high $\mathrm{NO}_{2}{ }^{-} / \mathrm{NO}_{3}{ }^{-}$ release, and NOS activity, which is not further stimulated by the addition of mitogens. ${ }^{57}$ It seemed therefore interesting to investigate a possible interaction of opioids on $\mathrm{NO}_{2}^{-} /$ $\mathrm{NO}_{3}{ }^{-}$release and NOS activity. Our results indicate that opioids can modify the release of $\mathrm{NO}_{2}{ }^{-} / \mathrm{NO}_{3}{ }^{-}$, and the enzymatic activity of NOS.

\section{Results}

\section{Opioids modify NO release in the culture medium}

Figure 1 presents the release of $\mathrm{NO}_{2}{ }^{-} / \mathrm{NO}_{3}{ }^{-}$in the culture medium of T47D cells, reflecting the release of $\mathrm{NO}$ (see Material and Methods). As shown, cells produce and release high concentrations of $\mathrm{NO}_{2}{ }^{-} / \mathrm{NO}_{3}{ }^{-}(920 \pm 19 \mu$ moles $/ \mathrm{L}$ as compared to the production and release of $30.5 \pm 5.1 \mu \mathrm{mol}$ I by MCF7 cells. ${ }^{57}$ This high release was not further enhanced by the $24 \mathrm{~h}$ stimulation of cells by the general mitogen phorbol

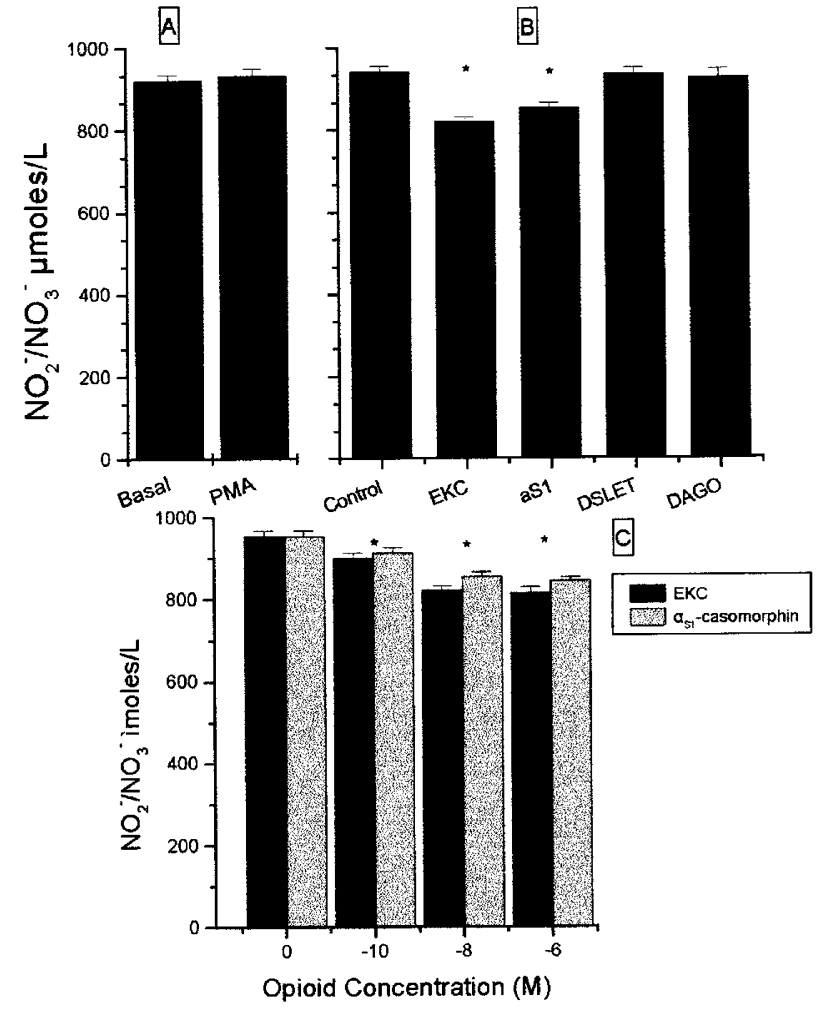

Figure 1 Release of $\mathrm{NO}_{2}{ }^{-} / \mathrm{NO}_{3}{ }^{-}$by T47D cells. (A) Basal and PMAstimulated $\mathrm{NO}_{2}{ }^{-} / \mathrm{NO}_{3}{ }^{-}$release after $24 \mathrm{~h}$ incubation. 200000 cells were incubated in 12-wells plates for $24 \mathrm{~h}$. Thereafter, medium was replaced, and cells were incubated for another $24 \mathrm{~h}$ period, in the absence (basal) or in the presence of $50 \mathrm{ng} / \mathrm{ml}$ of phorbol 12-myristate, 13-acetate (PMA). Medium was collected and stored at $-80^{\circ} \mathrm{C}$ until $\mathrm{NO}_{2}{ }^{-} / \mathrm{NO}_{3}{ }^{-}$determination, as described in the Material and Methods. (B) Basal $\mathrm{NO}_{2}-\mathrm{NO}_{3}{ }^{-}$release in the presence of opioid agonists. 200000 cells were incubated for $24 \mathrm{~h}$ after seeding. Thereafter, medium was replaced, and the indicated opioid drugs were added at a final concentration of $10^{-8} \mathrm{M}$. After $24 \mathrm{~h}$ incubation with the opioid drugs, medium was collected, centrifuged and $\mathrm{NO}_{2}{ }^{-} / \mathrm{NO}_{3}{ }^{-}$concentration was assayed. Mean \pm S.E. of three experiments in triplicates. EKC: Ethylketocyclazocine; aS1: $\alpha_{S 1}$-casomorphin; DSLET: [D-Ser ${ }^{2}$-Leu ${ }^{5}$-enkephalin]-Thr ${ }^{6}$; DAGO: [D-Ala ${ }^{2}, \mathrm{~N}-\mathrm{Me}-\mathrm{Phe}^{4}$, Gly ${ }^{5}$-ol]-enkephalin; *: $P<0.001$ (Student's one paired $t$-test), as compared to control. (C) Dose-effect of opioid agonists on the release of $\mathrm{NO}_{2}{ }^{-} / \mathrm{NO}_{3}{ }^{-}$in the culture medium. T47D cells were incubated for $24 \mathrm{~h}$ in the absence (0) or in the presence of the indicated concentrations of ethylketocyclazocine $(E K C)$ or alpha ${ }_{S_{1}}$-casomorphin. Then, the medium was collected and assayed for $\mathrm{NO}_{2}{ }^{-} / \mathrm{NO}_{3}{ }^{-}$, as described in Material and Methods. Mean \pm S.E. of three experiments in duplicate. No significant differences were observed between EKC and alpha $\mathrm{S}_{1}$-casomorphin. *: $P<0.05$ at least (Student's one paired $t$-test), as compared to values in the absence of opioids

12-myristate, 13-acetate (PMA). The addition of $10^{-8} \mathrm{M}$ of ethylketocyclazocine (EKC), acting on $\delta, \mu$ and $\kappa$ opioid receptors, or the $\kappa$-opioid agonist $\alpha_{\mathrm{S}_{1}}$-casomorphine ${ }^{2}$ decreased significantly the $\mathrm{NO}_{2}{ }^{-} / \mathrm{NO}_{3}{ }^{-}$released in the culture medium, while the addition of $10^{-8} \mathrm{M}$ DSLET or DAGO (selective $\delta$ - and $\mu$-opioid agonists respectively) had no effect, indicating that the action of EKC might be due to its $\kappa$-related activity. This opioid effect was equally not modified by the addition of PMA (not shown). The dose-dependence of the inhibition of $\mathrm{NO}_{2}{ }^{-} / \mathrm{NO}_{3}{ }^{-}$release is presented in Figure 1, lower panel (C). As shown, both opioid agonists inhibit the release of $\mathrm{NO}_{2}{ }^{-} / \mathrm{NO}_{3}{ }^{-}$after $24 \mathrm{~h}$ incubation in a dose- 
dependent manner. At a concentration of $10^{-8} \mathrm{M}$ both opioid agonists present a maximum effect on $\mathrm{NO}_{2}{ }^{-} / \mathrm{NO}_{3}{ }^{-}$release. Therefore, throughout this study, the effect of opioids on NOproducing system was assayed at that concentration $\left(10^{-8} \mathrm{M}\right)$. Interestingly, at this same concentration the maximum effect of opioid agonists on the arrest of cell growth was observed. ${ }^{2,56}$

\section{Opioids modify NO production}

The above decrease of $\mathrm{NO}_{2}{ }^{-} / \mathrm{NO}_{3}{ }^{-}$release by opioids indicates a direct or functional interaction between the opioid and the NO systems. As a first attempt to investigate a possible direct effect of opioids on NO production, we have assayed the effect of opioid agonists and antagonists on the kinetics of NO production, by flow cytometry. As shown in Figure 2, T47D cells, under basal conditions, produce significant amounts of $\mathrm{NO}$, a result reflected by the high release of $\mathrm{NO}_{2}{ }^{-} / \mathrm{NO}_{3}{ }^{-}$to the culture medium. After $1 \mathrm{~h}$, about $95 \%$ of cells are positive for NO. This effect is decreased (but not abolished) by the addition of the NOS antagonist L-NAME ( $\mathrm{N} \omega$-Nitro L-Arginin Methyl Ester), in a concentration-dependent manner (Figure 2, lower panel, insert).

The preincubation of cells with DSLET or DAGO (specific delta and $\mu$ opioid agonists respectively) for $10 \mathrm{~min}$ to $24 \mathrm{~h}$, did not produce any significant modification of NO production (not shown), confirming the results presented in Figure 1 (absence of effect of $\delta$ and $\mu$ opioid agonists on the concentration of $\mathrm{NO}_{2}{ }^{-} / \mathrm{NO}_{3}{ }^{-}$to the culture medium). In contrast, when cells were incubated with $10^{-8} \mathrm{M}$ ethylketocyclazocine, or $\alpha_{\mathrm{S} 1}$-casomorphine for the same time periods (10 $\min$ to $24 \mathrm{~h}$ ), a significant decrease of NO production was observed, varying from 25 to $60 \%$ of total fluorescence. For both opioid agonists this inhibition was very fast $\left(t_{1 / 2} \sim 3 \mathrm{~min}\right)$. In addition, when $\alpha_{\mathrm{S} 1^{-}}$ casomorphin was used to inhibit NO production, a decline of its inhibitory effect was observed after $24 \mathrm{~h}$, indicating a decline of the peptide potency, attributed to its partial degradation.

Diprenorphine is a general antagonist of opioid action. In T47D cells, this compound was found to inhibit the opioid receptor-mediated inhibition of cell proliferation. ${ }^{56}$ The incubation of cells with diprenorphine alone $\left(10^{-6} \mathrm{M}\right)$ decreased the production of $\mathrm{NO}$ after short (Figure $3 \mathrm{~A}$ ) or long incubation times (Figure $3 \mathrm{~B}$ ). The opioid agonist EKC and the antagonist diprenorphine showed similar kinetic curves applied alone or in combination, indicating that the observed effect of opioids on the production of NO might not be mediated through membrane opioid receptors.

\section{Opioids inhibit selectively the activity of NOS}

The above results indicate a direct action of opioids on the production of NO by T47D cells. In order to further analyze this action, cells were preincubated for $24 \mathrm{~h}$ with different opioid agonists, and total NOS activity was assayed in a whole cell homogenate. The results are presented in Figure 4A. As shown, a significant (by almost $50 \%$ ) inhibition of NOS activity
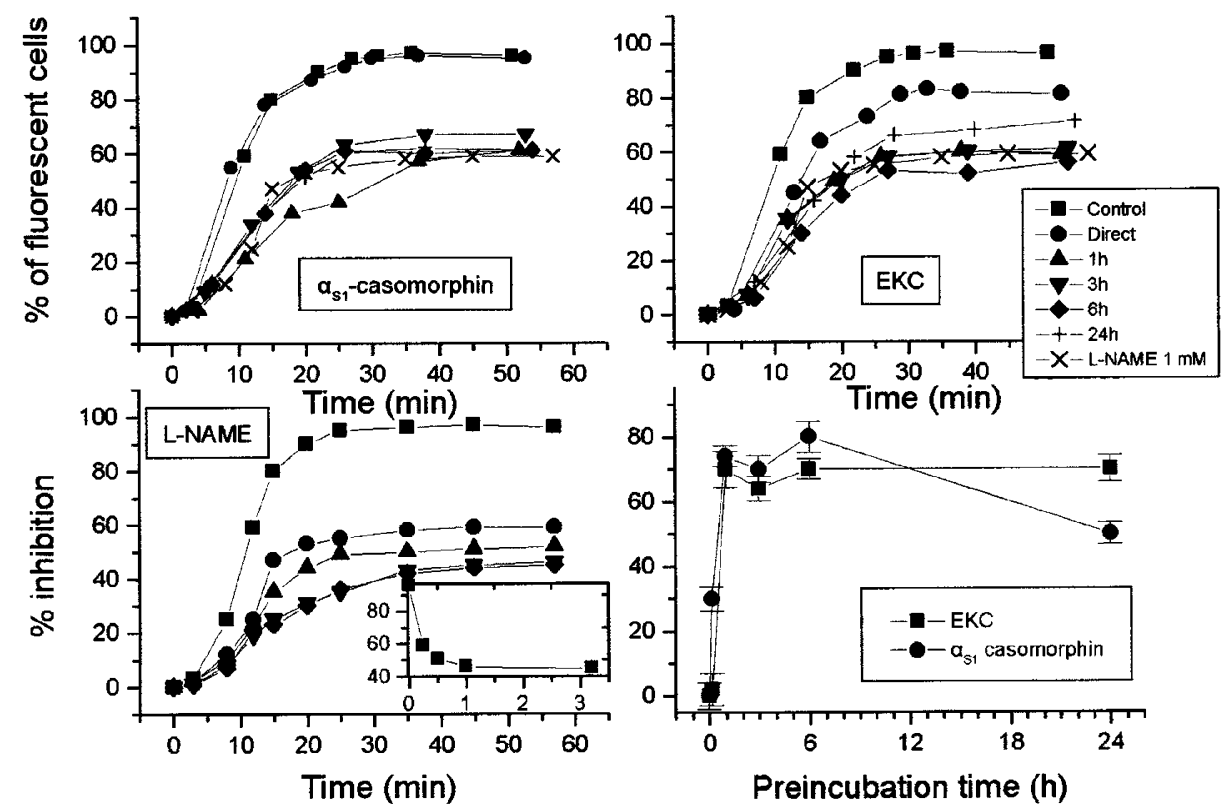

Figure 2 Kinetics of NO production. Upper panels: T47D cells were incubated for $24 \mathrm{~h}$ after seeding. Thereafter, medium was replaced and incubation was continued for the indicated time periods in the absence (control) or in the presence of $10^{-8} \mathrm{M}$ of opioids. Then, the medium was discarded, cells were detached from dishes, washed with PBS, loaded with diaminofluorescein diacetate, and NO production was assayed by flow cytometry, for 60 min. Results of an experiment, which was repeated five times with similar results. Lower panels: left: Inhibition of DAF fluorescence by L-NAME. L-NAME was applied 10 min prior to the onset of measurements. Square: control; Circle: $0.25 \mathrm{mM}$; Up triangle: $0.5 \mathrm{mM}$; Down triangle: $1 \mathrm{mM}$; Diamond: $3.2 \mathrm{mM}$. Insert: Maximal inhibition of intracellular fluorescence, as a function of L-NAME concentration (mM). The final points of the kinetic determination are plotted as a function of L-Name concentrations. Means + S.E. of three determinations. Right: Time dependence of opioid application on NO production. Data (final points of the kinetic experiments) are the means \pm S.E. of five different experiments 


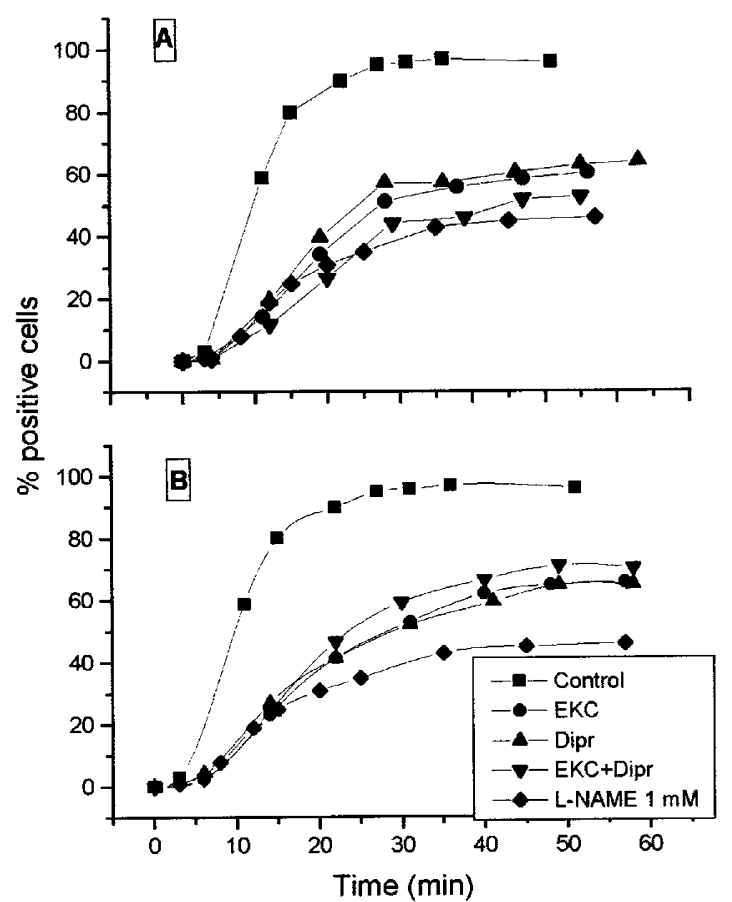

Figure 3 Effect of Diprenorphine on NO production in T47D cells after shor ( $1 \mathrm{~h}$, upper panel) or long ( $24 \mathrm{~h}$, lower panel) incubation. T47 cells were incubated without (control) or with $10^{-8} \mathrm{M}$ ethylketocyclazocine, in the absence, or in the presence of $10^{-6} \mathrm{M}$ diprenorphine, for $1 \mathrm{~h}(\mathbf{A})$ or $24 \mathrm{~h}(\mathbf{B})$. Thereafter, they were detached with thrypsin-EDTA, loaded with DAF, and fluorescence was measured by flow cytometry, during $60 \mathrm{~min}$. Results of a typical experiment. The above experiment was repeated four more times, with similar results. Intracellular fluorescence, in the presence of $1 \mathrm{mM} \mathrm{L-NAME}$ is presented, in order to evaluate the selective production of NO

was observed only after the application of EKC or $\alpha_{S_{1}}$ casomorphine $\left(10^{-8} \mathrm{M}\right)$. In contrast, DSLET or DAGO did not produce any significant effect, indicating that the effect of opioids might be restricted to $\kappa$-acting opioids. Preincubation of cells with diprenorphin $\left(10^{-6} \mathrm{M}\right)$ produced the same effect as described for EKC (Figure 4B). The incubation of cells with a combination of EKC $\left(10^{-8} \mathrm{M}\right)$ and diprenorphine $\left(10^{-6} \mathrm{M}\right)$ did not have any additional effect on NOS activity, confirming that the observed direct effect of $\kappa$-opioids might not be mediated by opioid receptors.

Figure 5 presents the substrate-related enzyme velocity of NOS in T47D cells. As shown, increasing concentrations of arginin increase the enzyme velocity, which reaches a plateau at concentrations $>42 \mu \mathrm{M}$ (see also Table 2). DSLET and DAGO did not show, as expected, any significant effect on enzyme velocity. In contrast, EKC and $\alpha_{S 1}$-casomorphine decreased significantly NOS activity, indicating a direct effect of opioids on the enzyme protein. Calculated $\mathrm{K}_{\mathrm{M}}$ and $\mathrm{V}_{\max }$ are presented in Table 2.

This opioid-related inhibition of NOS is dose-dependent. As shown in Figure 6 (upper panel), preincubation of cells with increasing concentrations of EKC or $\alpha_{S_{1}}$-casomorphin $\left(10^{-10}-10^{-6} \mathrm{M}\right)$ decrease, in a dose-dependent manner, the activity of the enzyme, similar to the effect of opioids on the enzyme activity in whole cell homogenates (Figure 6, lower panel).

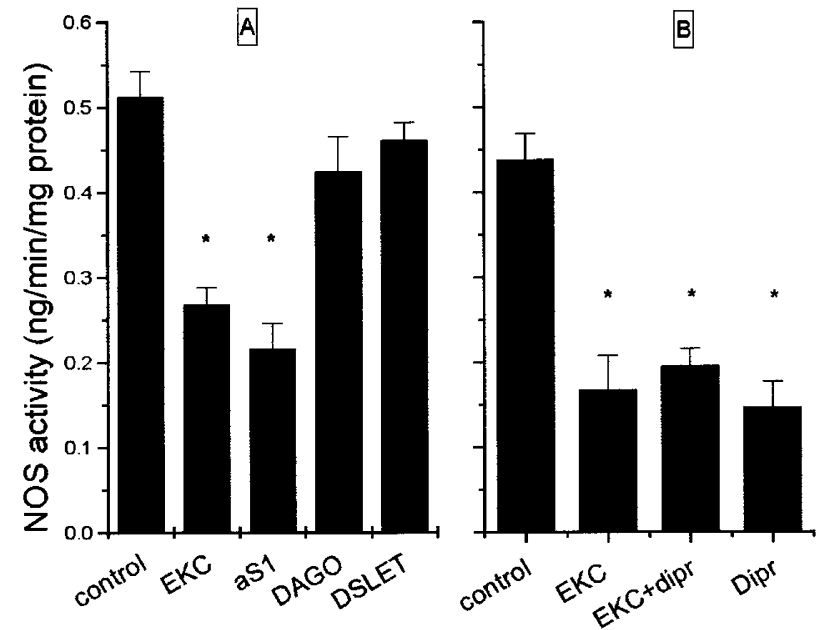

Figure 4 Effect of opioids on the activity of nitric oxide synthase. (A) Cells were preincubated for $24 \mathrm{~h}$ in the presence of $10^{-8} \mathrm{M}$ of the indicated opioid agonists. Then, they were harvested, homogenized, centrifuged at $12000 \times g$ for $15 \mathrm{~min}$, in order to eliminate nuclei and unbroken cells, and NOS activity was assayed in the supernatant as described in the Material and Methods section. (B) Cultured cells were harvested, the microsomal fraction was prepared as described above, and NOS activity was assayed, as described at the Material and Methods section, in the absence of opioid drugs (control) or in the presence of $10^{-8} \mathrm{M}$ of EKC, and/or $10^{-6} \mathrm{M}$ of the antagonist diprenorphine. Mean \pm S.E. of three experiments in duplicate. *: $P<0.001$, Student's one paired $t$-test, as compared to the control

\section{Effect of opioids on different isoforms of NOS}

Nitric oxide synthase exists in three different isoforms in mammalian species: eNOS, membrane bound, nNOS bound to different cellular membrane elements, and the cytosolic iNOS. These three isoforms have different molecular masses $(135,150$ and $130 \mathrm{kD}$ respectively) and are products of different genes. ${ }^{7}$ From another aspect, NOS molecules can be distinguished as calcium-dependent and calcium-independent, although no direct distinction of the three molecular isoforms could be made upon calcium dependence. Figure 7 presents the effect of $\kappa$-opioids on the activity of these $\mathrm{Ca}^{2+}$ dependent and independent isoforms of NOS. As shown, both ethylketocyclazocine and $\alpha_{S 1}$-casomorphine interact with both forms of the enzyme (calcium-dependent and independent). In contrast, the antagonist diprenorphine inhibits only the calcium-dependent NOS activity, indicating a differential action of opioid agonists and antagonists.

\section{Effect of FAD on opioid-related enzyme inhibition}

In the structure of NOS proteins two distinct domains can be identified: the reductase or FAD-FMN domain (towards the carboxylic end of the molecule) and the oxygenase or heme domain towards its $\mathrm{NH}_{2}$ part. ${ }^{58}$ An alignment of the three human types of NOS with the human $\kappa$ opioid receptor revealed that the later fits better with the FAD-FMN reductase domain of NOS, indicating a possible binding of opioids at this part of the molecule. In order to confirm this interaction, we have performed assays of the enzyme activity, in the presence or the absence of $10^{-8} \mathrm{M}$ ethylketocyclazocine, 


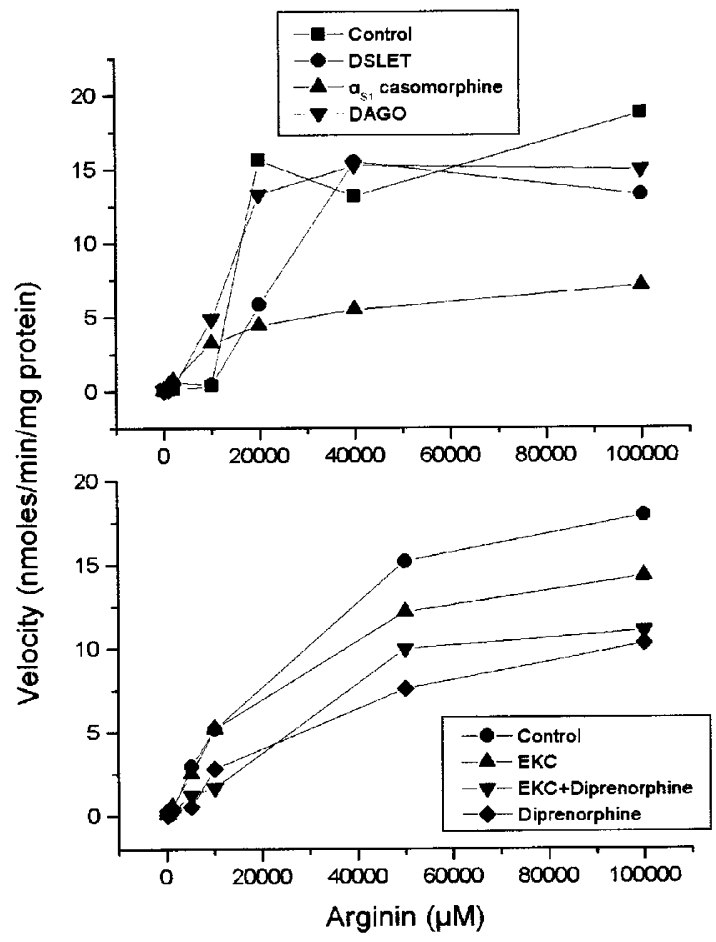

Figure 5 Effect of opioids on NOS reaction rate as a function of substrate (arginin) concentrations. T47D cells were harvested, nuclei and unbroken cells were eliminated as described in the legend of Figure 4, and NOS assay was performed as described in Material and Methods, in the presence of a constant concentration of labeled and increasing concentrations of unlabeled arginin, in the absence (control), or in the presence of $10^{-8} \mathrm{M}$ of the different opioid agonists. The opioid antagonist diprenorphine was added at $10^{-6} \mathrm{M}$. Results of a typical experiment, repeated three times with similar results

and varying concentrations of $\mathrm{FAD}$, from $10^{-7}$ to $10^{-4} \mathrm{M}$ (Figure 8). As shown, in the absence of the opioid agonist, the optimal concentration of FAD is $10^{-6} \mathrm{M}$. In contrast, when EKC is applied, the enzyme activity is decreased by about $40 \%$. Increasing the concentration of FAD restores the activity of the enzyme.

\section{Discussion}

Previous investigations have shown a functional interaction between the opioid system and $\mathrm{NO}$ in different cell types. ${ }^{12,14-16,19-22}$ In addition, NO-generating agents have been used as potential therapeutic drugs in opioid withdrawal syndromes, and NO was found to prevent morphine tolerance. Nevertheless, very few reports indicate a direct interaction between these two systems, ${ }^{23-26}$ usually restricted to the modulation of cGMP and/or other signaling molecules. ${ }^{17,18}$ The results of the present investigation indicate that, in T47D breast cancer cells, $\kappa$ - but not $\delta$ - or $\mu$ opioid agonists decrease $\mathrm{NO}_{2}{ }^{-} / \mathrm{NO}_{3}{ }^{-}$release, by a direct interaction on NOS.

Morphine and $\kappa$-opioid agonists, but not $\beta$-endorphin were found to inhibit nNOS at the $\mathrm{mM}$ range. ${ }^{59,60}$ Furthermore, $\delta$-, $\mu$-, or $\kappa$-opioids inhibit $\mathrm{NO}$ production in LPS-stimulated macrophages, in a concentration-dependent and reversible manner, indicating a functional coupling

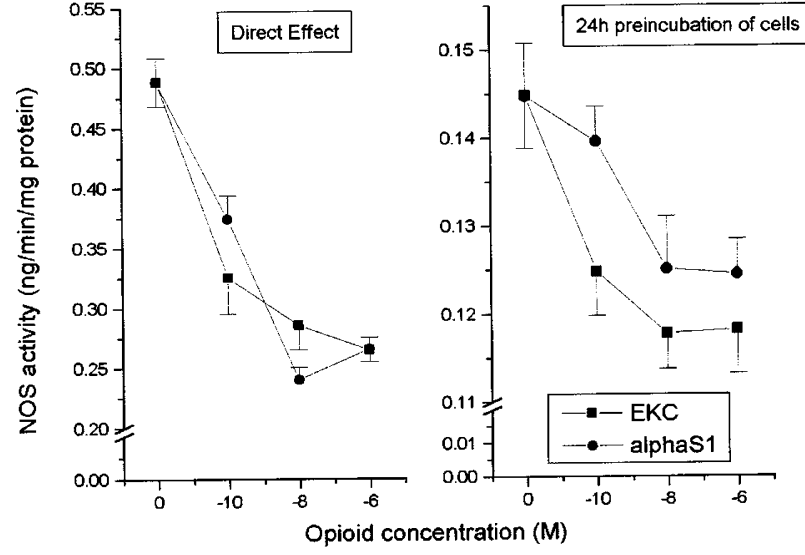

Figure 6 Dose-effect of opioids on NOS activity. Left panel: Whole cellular fraction of T47D cells was prepared and NOS activity was assayed as described in Material and Methods, in the absence (0) or in the presence of the indicated concentrations of ethylketocyclazocine (EKC) or alpha ${ }_{\mathrm{S} 1}$-casomorphin (alphaS1). Mean \pm S.E. of three experiments in duplicate. Right panel: T47D cells were incubated for $24 \mathrm{~h}$ in the absence $(0)$ or in the presence of the indicated concentrations of ethylketocyclazocine (EKC) or alphas 1 -casomorphin (alphaS1). Then, the medium was aspirated, cells were washed twice with ice-cold phosphate buffered saline, homogenized with a dounce glass homogenizer, and NOS activity was assayed in a whole homogenate, after elimination of unbroken cells and nuclei. Mean \pm S.E. of three experiments in duplicate

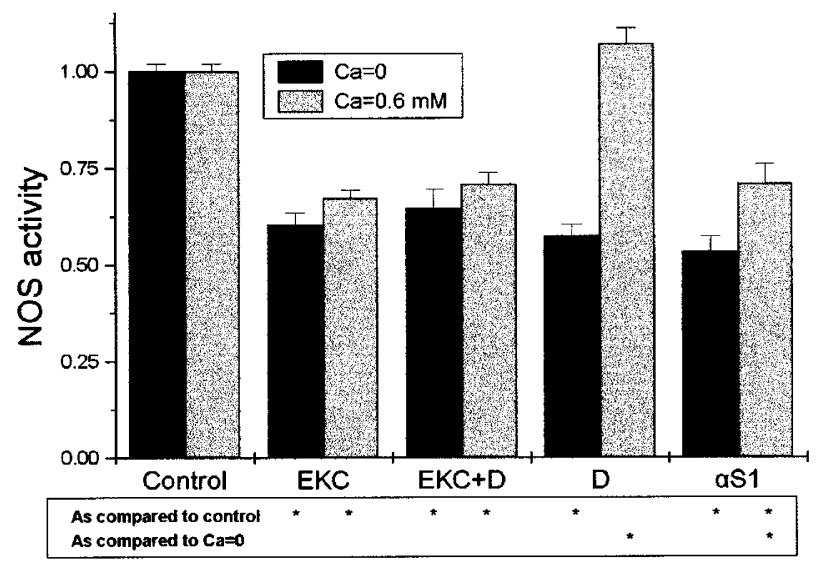

Figure 7 Effect of opioid agonists and antagonists on the calcium-dependent and independent NOS activity. Whole cellular fraction of T47D cells was prepared as described in Material and Methods. NOS assay, in the absence (control) or in the presence of the indicated opioid agonists, or antagonists $\left(10^{-8}\right.$ and $10^{-6} \mathrm{M}$ respectively) was performed in the absence (black bars) or in the presence (grey bars) of $0.6 \mathrm{mM} \mathrm{CaCl}_{2}$. Mean \pm S.E. of two experiments in triplicate. EKC: ethylketocyclazocine; D: Diprenorphine; aS1: $\alpha_{S_{1}}{ }^{-}$ casomorphin. *: $P<0.05$ at least (one tailed Student's $t$-test)

of the two systems, ${ }^{61}$ possibly mediated through opioid receptors. ${ }^{62}$ Increased NOS activity was found in the spinal cord of morphine-exposed animals. ${ }^{63}$ In addition, it was reported that heroin administration reduces the expression of LPS-stimulated iNOS activity in rat liver, spleen and lung, through an opioid receptor-mediated mechanism. ${ }^{64}$ Finally, $\mathrm{U}-50488 \mathrm{H}$, a $\kappa$-opioid agonist, ${ }^{59}$ inhibits nNOS activity in vitro, while NO blocks the opioid-induced tolerance in vivo. $^{65-67}$ 


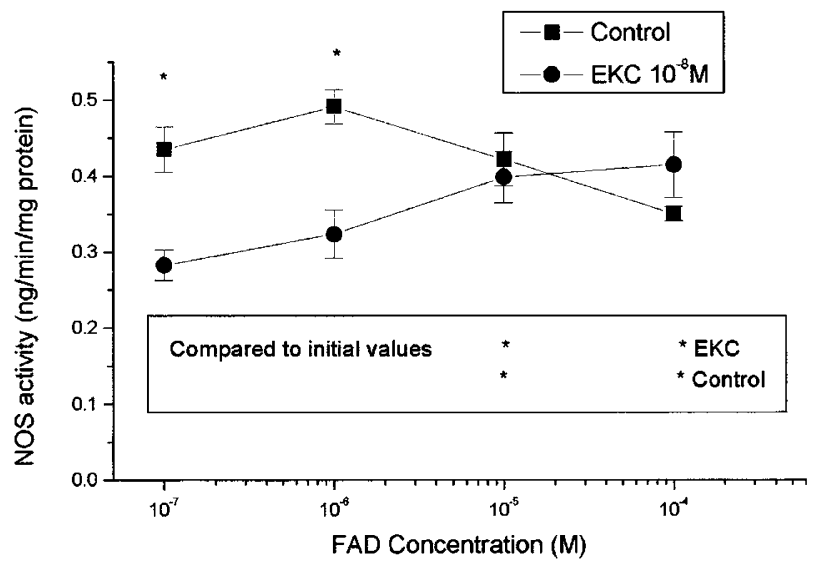

Figure 8 Effect of FAD concentration on NOS activity. Action of opioid agonists. Whole cellular fraction of T47D cells was prepared as indicated in the Material and Methods section. The activity of NOS was assayed in the absence (control) or in the presence of $10^{-8} \mathrm{M}$ of the opioid agonist ethylketocyclazocine $(E K C)$, and varying concentrations of $F A D$, ranging from $10^{-7}$ to $10^{-4} \mathrm{M}$. Results of three experiments, in duplicate. *: $P<0.05$ at least, one paired Student's $t$-test. In the box the statistical comparison of data as compared to their corresponding initial value are presented

In the T47D cell line, previous results have shown that low concentrations of $\kappa$-opioids decrease cell growth in a time-, dose-dependent and reversible manner. ${ }^{2,56} \mathrm{We}$ report here that opioid agonists, active on $\kappa$-opioid receptors decrease $\mathrm{NO}_{2}{ }^{-} / \mathrm{NO}_{3}{ }^{-}$release to the cell culture medium (Figure 1), and the activity of NOS (Figures $3 \mathrm{~A}$ and 6 ) in a similar dose-dependent manner. In contrast, $\delta$ - and $\mu$-acting opioid agonists (DSLET and DAGO respectively) had no effect (Figures 1, 4 and 5, Tables 1 and 2). The general opioid antagonist diprenorphine exhibits an inhibitory action on NOS too, indicating a non-opioid receptor-mediated phenomenon (Figures 3 and 4). In addition, diprenorphine action is restricted to the calciumdependent fraction of NOS, while ethylketocyclazocine and $\alpha_{\mathrm{S} 1}$-casomorphine act on both calcium dependent and independent fractions (Figure 7), indicating a differential action of opioid agonists and antagonists, possibly due to a different conformation of agonist and antagonist molecules. Previous results indicate that, in the vascular endothelium, opioid receptors could be coupled to cNOS, ${ }^{24-26}$ although in this case opioid agonists produce an increase of the enzyme activity. In our hands, however, no effect of $\mu$ acting opioids (DAGO) was found, a discrepancy possibly due to tissue differences in the two studies. Indeed, T47D cells express preferentially $\kappa$ opioid sites, which are predominant, ${ }^{56}$ while no $\mu$ - and rare $\delta$-opioid sites have been identified, with $\mu$-opioid agonists acting through somatostatin receptors. ${ }^{54}$ Preliminary, unpublished, results from our laboratory indicate that somatostatin analogs cannot modify NOS activity. Finally, our results indicate that the observed opioid action is exerted directly on the enzyme molecule (Figures 3B, 4 and 6).

The mechanism of the direct inhibitory action of opioids on NOS is not clear. Our results give some hints on this interaction: Opioids that inhibit directly the enzyme activity (ethylketocyclazocine, $\alpha_{\mathrm{S} 1}$-casomorphine and diprenor-
Table 1 Kinetic characteristics of NO production in T47D cells: Effect of opioids

\begin{tabular}{lcl}
\hline & Maximum (\%) & \multicolumn{1}{c}{$\mathbf{k}_{\mathbf{1}} \mathbf{~ m i n}^{-\mathbf{1}}$} \\
\hline Control & $96 \pm 3$ & $0.1097 \pm 0.007$ \\
EKC & $61 \pm 5^{\star}$ & $0.0366 \pm 0.011^{*}$ \\
$\alpha_{\text {s1 }}$-casomorphin & $61 \pm 4^{\star \star}$ & $0.0366 \pm 0.012^{*}$ \\
DSLET & $94 \pm 5$ & $0.1113 \pm 0.005$ \\
DAGO & $97 \pm 3$ & $0.1064 \pm 0.008$ \\
EKC+Diprenorphine & $63 \pm 4^{*}$ & $0.0357 \pm 0.009^{*}$ \\
Diprenorphine & $60 \pm 5^{*}$ & $0.0375 \pm 0.015^{*}$ \\
\hline
\end{tabular}

Cells, cultured for $24 \mathrm{~h}$ in the absence (control) or in the presence of $10^{-8} \mathrm{M}$ of the indicated opioids were loaded with diaminofluorescein diacetate, and the production of NO was measured by the increase of specific fluorescence. The general opioid antagonist diprenorphine was applied at a concentration of $10^{-6} \mathrm{M}$. Data were analyzed by the application of the first order kientic equation: $\log (a /(a-x))=k t / 2.303$, in which $a$ is the percentage of negative cells $(100 \%$ at time 0$), x$ is the percentage of positive cells at time $t$, and $k$ is the kinetic rate constant, expressed as $\min ^{-1}$ (83). Mean + S.E. of five different measurements. ${ }^{*}: P<0.05,{ }^{* *}: P<0.01$ (two-tailed test)

Table 2 Calculation of the Michaelis constant $\left(\mathrm{K}_{\mathrm{M}}\right)$ the maximal velocity $\left(\mathrm{V}_{\max }\right)$ and the Hill coefficient of data presented in Figure 4, according to Dawes. ${ }^{83}$ Mean \pm S.E. of three different experiments performed in duplicate

\begin{tabular}{lccc}
\hline & $\begin{array}{c}\mathbf{K}_{\mathbf{M}} \\
(\mu \mathbf{M})\end{array}$ & $\begin{array}{c}\mathbf{V}_{\text {max }} \\
\text { (nmoles/min/ } \\
\text { mg protein) }\end{array}$ & $\begin{array}{c}\text { Hill } \\
\text { coefficient }\end{array}$ \\
\hline Control & $20.7 \pm 2.1$ & $18.8 \pm 2.0$ & $1.59 \pm 0.2$ \\
DSLET & $21.4 \pm 3.2$ & $15.5 \pm 1.7$ & $1.52 \pm 0.4$ \\
DAGO & $22.2 \pm 2.7$ & $15.2 \pm 1.3$ & $1.68 \pm 0.5$ \\
$\alpha_{\text {s1 }}$-casomorphin & $12.3 \pm 3.7^{*}$ & $7.1 \pm 0.8^{* *}$ & $1.02 \pm 0.2^{*}$ \\
EKC & $22.2 \pm 2.5$ & $16.1 \pm 0.9$ & $1.21 \pm 0.2$ \\
Diprenorphine & $39.9 \pm 3.4^{* *}$ & $13.7 \pm 1.1^{*}$ & $1.25 \pm 0.3$ \\
EKC+Diprenorphine & $22.2 \pm 2.8$ & $11.5 \pm 1.0^{*}$ & $1.30 \pm 0.2$ \\
\hline
\end{tabular}

${ }^{*}: P<0.05,{ }^{* *}: P<0.01$ (one tail $t$-test)

phine) decrease significantly the Hill coefficient (see Table 2), indicating a possible dissociation of the NOS dimer, which is considered as the only active form of the enzyme. ${ }^{7}$ Furthermore, data presented in Table 2 indicate a non-competitive inhibition of enzyme activity. ${ }^{68}$ The mechanistics of this type of inhibition indicate that opioids could bind to free and substrate-bound enzyme molecules, suggesting that they interact with a different site than that of arginin binding. Finally, alignment of the human $\kappa$-opioid receptor and the three human NOS sequences indicates that opioid agonists or antagonists might bind to reductase moiety of the NOS molecules, a result further indicated by the data presented in Figure 8, showing that increasing concentrations of FAD restore the enzymatic activity.

Our results show a very rapid inhibitory action of opioids on NO production (Figure 2), indicating that, perhaps, a receptor-mediated interaction could not be ruled out. Nevertheless, the fact that agonists and antagonists produce similar results indicates that, if a receptor-mediated action occurs, this might be mediated by another membrane receptor, different from opioid receptors. In addition, if the direct interaction of opioids on NOS molecules reported here, has a biological significance, opioid ligands might be present in the cytosol in an active form, after an extracellular application. A number of reports indicate that, after opioid treatment, the receptor-ligand complexes enter cells through 
early then late endosomes and directed to lysosomes for degradation of either receptor and/or ligand. This intracellular trafficking of the receptor-ligand complex occurs minutes after ligand application, and reaches its maximum after $4 \mathrm{~h} .{ }^{69,70}$ Thereafter, if the ligand is applied for short periods ( $\mathrm{min})$ the receptor is redistributed to the plasma membrane, other ways it is directed to lysosomes for degradation. ${ }^{69}$ The fate of opioid ligands is not well established. Alkaloids, being hydrophobic, could enter directly in the cytoplasm. In contrast, peptide ligands require an active transport through receptor-mediated endocytosis, and are either degraded, or they could exert specific intracellular effects. Indeed, betaendorphin has been found to interact with intracellular binding sites, after its extracellular application, indicating internalization in an active form, ${ }^{71}$ while encephalin analogs were found to recycle to the culture medium after endocytosis of the ligand-receptor complex, and lysosomal receptor degradation. ${ }^{72}$ Human $\kappa$ opioid receptors are internalized also rapidly, with $\mathrm{t}_{1 / 2}$ of about $10 \mathrm{~min}$, and about $40 \%$ of them are found in the cytoplasm after $20 \mathrm{~min}$ exposure to the ligand. ${ }^{73}$ Interestingly, after agonist removal, receptors could recycle to the plasma membrane, ${ }^{73}$ although other reports indicate that kappa selective peptides induce receptor downregulation. ${ }^{74} \mathrm{~A}$ recent report indicates that receptor degradation, involving down regulation, occurs by a combined action of lysosomes and proteasomes. ${ }^{75}$ The above results indicate that receptor and/or ligand internalization is very rapid, occurring in minutes after receptor-ligand interaction, and could explain our results, of a very rapid opioid action on NOS activity (Figure 2).

The direct interaction of opioids with NOS, and the decrease of the enzyme activity reported here, opens new, interesting, possibilities for breast tumor biology. NO has been implied to tumor progression and metastasis, ${ }^{11}$ while opioids, provided either by the general circulation, or locally produced, were found to decrease cell growth. ${ }^{2,55,56,76}$ It is therefore tentative to relate the reported inhibition of NOS activity and NO production and release by opioids to tumor metastasis suppression, indicating a potential action of opioids in tumor biology and treatment.

\section{Materials and Methods}

\section{Material and cell line}

T47D cells were purchased from the European Collection of Cell Cultures (Salisbury, UK). They were cultured in RPMI-1640 medium supplemented with $10 \%$ fetal bovine serum (FBS), in a humidified atmosphere of $5 \% \mathrm{CO}_{2}$ in air. All culture media and sera were from Gibco BRL (Life Technologies, Paisley, UK). Medium, supplemented with the different compounds was changed every day.

DAGO and DSLET were from Sigma Chemical Co. (St Louis MO, USA). EKC was a gift from Sterling-Winthrop (Bayer Co., Leverkusen, Germany). Diprenorphine was from Reckit and Coleman Co.

\section{Nitric oxide generation and assay}

Cells were seeded in 12-well plates, at a density of 200000 cells/well. Twenty-four hours later, the medium was replaced, and opioids or an equivalent volume of PBS (negative control) were added. After another 24-h incubation, media were collected, centrifuged and frozen at $-80^{\circ} \mathrm{C}$, for $\mathrm{NO}_{2}{ }^{-} / \mathrm{NO}_{3}{ }^{-}$determination.

$\mathrm{NO}$ is relatively unstable in the presence of molecular oxygen $\left(\mathrm{O}_{2}\right)$. Therefore, it is rapidly and spontaneously autooxidized, in aqueous (physiological) fluids to give the stable nitrite $\left(\mathrm{NO}_{2}{ }^{-}\right.$), and (possibly through the action of certain oxyhemoproteins) nitrate $\left(\mathrm{NO}_{3}{ }^{-}\right)$ions. We have therefore measured these metabolites, as described by Grisham et $a l^{77}$ and Granger et al. ${ }^{78}$ Briefly, $100 \mu \mathrm{l}$ of the culture medium were incubated with $0.1 \mathrm{U}$ of nitrate reductase, from Aspergillus, for $30 \mathrm{~min}$ at $37^{\circ} \mathrm{C}$, in $25 \mu \mathrm{l}$ of $1 \mathrm{M}$ HEPES buffer (pH 7.4), $25 \mu \mathrm{l}$ of $0.1 \mathrm{mM} \mathrm{FAD}$ and $50 \mu \mathrm{l}$ of $1 \mathrm{mM} \mathrm{NADPH}$, in a total volume of $500 \mu \mathrm{l}$. This incubation transforms $\mathrm{NO}_{3}{ }^{-}$to $\mathrm{NO}_{2}{ }^{-}$. Thereafter, $5 \mu \mathrm{l}$ of lactate dehydrogenase $(1500 \mathrm{U} / \mathrm{ml})$ and $50 \mu \mathrm{l}$ of $100 \mathrm{mM}$ pyruvate were added in each tube, in order to oxidize any unreacted NADPH, which inhibits strongly the Griess reaction. Samples were incubated at $37^{\circ} \mathrm{C}$ for $10 \mathrm{~min}$. Subsequently, $1 \mathrm{ml}$ of the Griess reagent (equal volumes of $0.2 \%(\mathrm{w} / \mathrm{v}) \mathrm{N}-(1$ naphtyl)ethylenediamine, and $2 \%(\mathrm{w} / \mathrm{v})$ sulfanilamide in $5 \%$ phosphoric acid, premixed shortly prior to use) was added, followed by $10 \mathrm{~min}$ incubation at room temperature. Absorbance was measured at $543 \mathrm{~nm}$, and was linear with standard nitrite concentrations ranging from 2-60 $\mu \mathrm{M}$. All reagents used were from Sigma (St Louis, MO, USA).

NO production by T47D cells was measured using the diaminofluorescein diacetate method ${ }^{79,80}$ and flow cytometry. Briefly, cells, treated or not with opioids for the indicated time periods, were detached from dishes using a trypsin-EDTA solution (Gibco BRL, Life Technologies, Paisley, UK), adjusted to a concentration of $10^{6} \mathrm{cells} / \mathrm{ml}$, and diaminofluorescein diacetate $(0.1 \mathrm{mM}$ final concentration in a volume of $10 \mu \mathrm{l})$, obtained from Sigma (St Louis, MO, USA) was added. NO production was assayed by flow cytometry, using a Coulter Epics XL-MCL apparatus (Beckman-Coulter Inc., Foullerton, CA, USA), using an excitation wavelength of $485 \mathrm{~nm}$ (20-nm bandwidth) and an emission wavelength of 530 (25-nm bandwidth). The principle of the methods resides to the deacetylation of the dye by intracellular esterases to form diaminofluorescin (DAF), which, in turn, is transformed to the fluorescent dye 2', 7'-diaminofluorescein under the action of NO. This dye remains trapped in the cell and can therefore be measured by flow cytometry. It was reported that DAF, in neutral solutions as the cellular environment, does not react with other oxidized forms of NO, such as $\mathrm{NO}_{2}$ and $\mathrm{NO}_{3}$, or other reactive nitrogen or oxygen species. ${ }^{80}$ Nevertheless, in order to confirm these results, and to rule out other possible sources of fluorescence, we have considered as NO-related specific fluorescence the difference of the total fluorescent signal and that obtained in the presence $1 \mathrm{mM}$ of the NOS inhibitor L-NAME. In addition, we have used as a blank in all our measurements a mixture of $\operatorname{DAF}(0.1 \mu \mathrm{M})$ and opioids $\left(10^{-8} \mathrm{M}\right)$, in the absence of cells.

\section{Nitric oxide synthase assay}

Nitric oxide synthase (NOS) activity was assayed, by the transformation of radioactive arginine to citrulline ${ }^{81,82}$ Briefly, cells were detached from dishes by Thrypsin-EDTA, washed with phosphatebuffered saline (PBS), harvested in PBS-1 mM EDTA, and homogenized with repeated pipetting with $250 \mu$ l homogenization buffer (250 mM Tris-EDTA, $10 \mathrm{mM}$ EDTA, $10 \mathrm{mM}$ EGTA). Nuclei and unbroken cells were separated by centrifugation at $12000 \times g$ for $15 \mathrm{~min}$, and discarded, while the supernatant was used for the assay of NOS. The concentration of proteins was adjusted at $10 \mu \mathrm{g} / \mathrm{ml}$. A reaction mixture (sufficient for 10 data points) is prepared, with $250 \mu \mathrm{l}$ 
of $50 \mathrm{mM}$ Tris $-\mathrm{HCl} \mathrm{pH} 7.4$ containing $6 \mu \mathrm{M}$ tetrahydrobiopterin, $2 \mu \mathrm{M}$ flavin adenine dinucleotide and $2 \mu \mathrm{M}$ flavin adenine mononucleotide, $50 \mu \mathrm{l}$ of $10 \mathrm{mM} \mathrm{NADPH}, 10 \mu \mathrm{l}\left[{ }^{3} \mathrm{H}\right]$ Arginine (Amersham, Buckinghamshire, UK), $50 \mu \mathrm{l}$ of $6 \mathrm{mM} \mathrm{CaCl}_{2}$ and $40 \mu \mathrm{l}$ distilled water. Fourty $\mu \mathrm{l}$ of this reaction mixture were mixed with $10 \mu \mathrm{l}$ of the protein extract and incubated for $1 \mathrm{~h}$ at $37^{\circ} \mathrm{C}$. During this incubation time $\left[{ }^{3} \mathrm{H}\right]$-arginine is converted by NOS to $\left[{ }^{3} \mathrm{H}\right]$-citrulline. The reaction was stopped with $400 \mu$ l of ice-cold 50 mM HEPES (pH 5.5)-5 mM EDTA. Non-reacted arginine was eliminated by resin absorption (AG $50 \mathrm{Wx}^{*}$, BioRad Laboratories, Hercules, CA, USA). The eluate was mixed with scintillation fluid (SigmaFluor, Sigma, St Louis, MO, USA) and the radioactivity was measured in a liquid scintillation counter (Tricarb, Packard, Instrument Co., Meriden, CT, USA), with $60 \%$ efficiency for tritium. For the detection of calcium-independent NOS isoforms, $\mathrm{CaCl}_{2}$ was replaced by water. In order to assay the effect of FAD on the enzyme activity, different concentrations of $F A D$, ranging from $10^{-7}$ $10^{-4} \mathrm{M}$, were introduced in the reaction mixture, in the presence or the absence of $10^{-8} \mathrm{M}$ EKC.

\section{Calculations}

All calculations were performed using the Origin v 5.0 microcomputer program (Northampton, MA, USA). Statistical analysis (ANOVA, Student's $t$-test), were made by the use of Systat $v 9.0$ (SPSS Science, Chicago IL, USA) microcomputer program.

\section{Acknowledgements}

Work partially supported by grants from the General Secretariat of Research and Technology (GGET), the Ministry of Health (KESY), and Varelas S.A.

\section{References}

1. LaForge KS, Yuferov V and Kreek MJ (2000) Opioid receptor and peptide polymorphisms: Potential implications for addictions. Eur. J. Pharmacol. 410: 249-268

2. Kampa M, Loukas S, Hatzoglou A, Martin P and Martin P-M (1996) Identification of a novel opioid peptide derived from alpha-S1 human casein (alpha-S1 casomorphin, and alpha-S1 casomorphin-amide). Biochem. J. 319: 903-908

3. Kampa M, Bakogeorgou E, Hatzoglou A, Damianaki A, Martin PM and Castanas E (1997) Opioid alkaloids and casomorphin peptides decrease the proliferation of prostatic cancer cell lines (LNCaP, PC3 and DU145) through a partia interaction with opioid receptors. Eur. J. Pharmacol. 335: 255-265

4. Panagiotou S, Bakogeorgou E, Papakonstanti E, Hatzoglou A, WalletF, Dussert C, Stournaras C, Martin PM and Castanas E (1999) Opioid agonists modify breast cancer cell proliferation by blocking cells to the G2/M phase of the cycle: involvement of cytoskeletal elements. J. Cell. Biochem. 73: 204-211

5. Papakonstanti EA, Bakogeorgou E, Castanas E, Emmanouel DS, Hartig R and CS (1998) Early alterations of actin cytoskeleton in OK cells by opioids. J. Cell. Biochem. 70: 60-69

6. Zajac JM and Roques BP (1983) Differential properties of mu and delta opiate binding sites studied with highly selective ligands. Life Sci. 33 (Suppl. 1): 155 158

7. Marletta MA, Hursman AR and Rusche KM (1998) Catalysis by nitric oxide synthase. Curr. Opinion Chem. Biol. 2: 656-663

8. Stuehr DJ (1999) Mammalian nitric oxide synthases. Biohim. Biophys. Acta. 1411: $217-230$

9. Denninger JW and Marletta MA (1999) Guanylate cyclase and the NO/cGMP signaling pathway. Biochim. Biophys. Acta. 1411: 334-350

10. Colasanti Mand Suzuki H (2000) The dual personality of NO. Trends Pharmacol. Sci. 21:249-252
11. WinkDA, Vodovotz Y, Laval J, Laval F, Dewhirst MW and Mitchell JB (1998) The multifaceted roles of nitric oxide in cancer. Carcinogenesis. 19: 711-721

12. Adams ML, MeyerER and Cicero TJ (1996) Effects of nitric oxide-related agents on opioid regulation of rat testicular steroidogenesis. Biol. Reprod. 54: 11281134

13. Budziszewska B, Leskiewicz M, Jaworska-Feil L and Lason W (1999) The effect of $\mathrm{N}$-nitro-L-arginine methyl ester on morphine-induced changes in the plasma corticosterone and testosterone levels in mice. Exp. Clin. Endocrinol. Diabetes. 107: $75-79$

14. Bhargava HN, Bian JT and Kumar S (1997) Mechanism of attenuation of morphine antinociception by chronic treatment with L-arginine. J. Pharmacol. Exp. Ther. 281: $707-712$

15. Bhargava HN and Bian JT (1998) Effects of acute administration of L-arginine on morphine antinociception and morphine distribution in central and peripheral tissues of mice. Pharmacol. Biochem. Behav. 61: 29-33

16. Babey AM, Kolesnikov Y, Cheng J, Inturrisi CE, Trifilletti RR and Pasternak GW (1994) Nitric oxide and opioid tolerance. Neuropharmacology 33: 1463-1470

17. Bhargava $\mathrm{HN}$ and Cao YJ (1997) Effect of chronic administration of morphine, $U$ $50,488 \mathrm{H}$ and [D-Pen2, D- Pen5]enkephalin on the concentration of cGMP in brain regions and spinal cord of the mouse. Peptides 18: 1629-1634

18. Pu S, Horvath TL, Diano S, Naftolin F, Kalra PS and Kalra SP (1997) Evidence showing that beta-endorphin regulates cyclic guanosine $3^{\prime}, 5^{\prime}$ - monophosphate (cGMP) efflux: anatomical and functional support for an interaction between opiates and nitric oxide [published erratum appears in Endocrinology 1997 Jun; 138(6): 2609]. Endocrinology 138: 1537-1543

19. Lomniczi A, Mastronardi CA, Faletti AG, Seilicovich A, De Laurentiis A, McCann SM and Rettori V (2000) Inhibitory pathways and the inhibition of luteinizing hormone-releasing hormone release by alcohol. Proc. Natl. Acad. Sci. USA 97: $2337-2342$

20. Faletti AG, Mastronardi CA, Lomniczi A, Seilicovich A, Gimeno M, McCann SM and Rettori V (1999) beta-Endorphin blocks luteinizing hormone-releasing hormone release by inhibiting the nitricoxidergic pathway controlling its release. Proc. Natl. Acad. Sci. USA 96: 1722-1726

21. Bhat GK, Mahesh VB, Ping L, Chorich L, Wiedmeier VT and Brann DW (1998) Opioid-glutamate-nitric oxide connection in the regulation of luteinizing hormone secretion in the rat. Endocrinology 139: 955-960

22. Prevot V, Rialas CM, Croix D, Salzet M, Dupouy JP, Poulain P, Beauvillain JC and Stefano GB (1998) Morphine and anandamide coupling to nitric oxide stimulates $\mathrm{GnRH}$ and $\mathrm{CRF}$ release from rat median eminence: neurovascular regulation. Brain Res. 790: 236-244

23. Bilfinger TV, Salzet M, Fimiani C, Deutsch DG, Tramu G and Stefano GB (1998) Pharmacological evidence for anandamide amidase in human cardiac and vascular tissues. Int. J. Cardiol. 64 Suppl 1: S15-S22

24. Stefano GB, Goumon Y, Bilfinger TV, Welters ID and Cadet P (2000) Basal nitric oxide limits immune, nervous and cardiovascular excitation: human endothelia express a mu opiate receptor. Prog. Neurobiol. 60: 513-530

25. Stefano GB, Salzet M, Magazine HI and Bilfinger TV (1998) Antagonism of LPS and IFN-gamma induction of iNOS in human saphenous vein endothelium by morphine and anandamide by nitric oxide inhibition of adenylate cyclase. $\mathrm{J}$. Cardiovaso. Pharmacol. 31: 813-820

26. Stefano GB, Hartman A, Bilfinger TV, Magazine HI, Liu Y, Casares F and Goligorsky MS (1995) Presence of the mu3 opiate receptor in endothelial cells. Coupling to nitric oxide production and vasodilation. J. Biol. Chem. 270:3029030293

27. Wilderman MJ and Armstead WM (1998) Role of endothelial nitric oxide synthase in hypoxia-induced pial artery dilation. J. Cereb. Blood Flow Metab. 18: $531-538$

28. Wilderman MJ and Armstead WM (1997) Role of neuronal NO synthase in relationship between $\mathrm{NO}$ and opioids in hypoxia-induced pial artery dilation. Am. J. Physiol. 273: H1807-H1815

29. Lue WM, Su MT, Lin WB and Tao PL (1999) The role of nitric oxide in the development of morphine tolerance in rathippocampal slices. Eur. J. Pharmacol. 383: $129-135$

30. Powell KJ, Hosokawa A, Bell A, Sutak M, Milne B, Quirion R and Jhamandas K (1999) Comparative effects of cyclo-oxygenase and nitric oxide synthase inhibition on the development and reversal of spinal opioid tolerance. $\mathrm{Br}$. J. Pharmacol. 127: 631-644 
31. Aley KO and Levine JD (1997) Different mechanisms mediate development and expression of tolerance and dependence for peripheral mu-opioid antinociception in rat. J. Neurosci. 17: 8018-8023

32. Bhargava HN (1995) Attenuation of tolerance to, and physical dependence on, morphine in the rat by inhibition of nitric oxide synthase [published erratum appears in Gen Pharmacol 1996 Apr;27(3):557]. Gen. Pharmacol. 26: 1049 1053

33. Majeed NH, Przewlocka B, Machelska H and Przewlocki R (1994) Inhibition of nitric oxide synthase attenuates the development of morphine tolerance and dependence in mice. Neuropharmacology 33: 189-192

34. Pineda J, Torrecilla M, Martin-Ruiz R and Ugedo L (1998) Attenuation of withdrawal-induced hyperactivity of locus coeruleus neurones by inhibitors of nitric oxide synthase in morphine-dependent rats. Neuropharmacology 37: $759-767$

35. Highfield DA and Grant S (1998) Ng-nitro-L-arginine, an NOS inhibitor, reduces tolerance to morphine in the rat locus coeruleus. Synapse. 29: 233-239

36. Hall S, Milne B and Jhamandas K (1996) Nitric oxide synthase inhibitors attenuate acute and chronic morphine withdrawal response in the rat locus coeruleus: an in vivo voltammetric study. Brain Res. 739: 182-191

37. Vaupel DB, Kimes AS and London ED (1995) Nitric oxide synthase inhibitors Preclinical studies of potential use for treatment of opioid withdrawal. Neuropsychopharmacology 13: 315-322

38. Herman BH, Vocci F and Bridge P (1995) The effects of NMDA receptor antagonists and nitric oxide synthase inhibitors on opioid tolerance and withdrawal. Medication development issues for opiate addiction. Neuropsychopharmacology 13: 269-293

39. VaupelDB, Kimes AS and London ED (1995) Comparison of 7-nitroindazole with other nitric oxide synthase inhibitors as attenuators of opioid withdrawal. Psychopharmacology (Berl). 118: 361-368

40. London ED, Kimes AS and Vaupel DB (1995) Inhibitors of nitric oxide synthase and the opioid withdrawal syndrome. NIDA Res. Monogr. 147: 170-181

41. Kolesnikov YA, Pick CG, Ciszewska G and Pasternak GW (1993) Blockade of tolerance to morphine but not to kappa opioids by a nitric oxide synthase inhibitor. Proc. Natl. Acad. Sci. USA 90: 5162-5166

42. Adams ML, Kalicki JM, Meyer ER and Cicero TJ (1993) Inhibition of the morphine withdrawal syndrome by a nitric oxide synthase inhibitor, NG-nitro-L-arginine methyl ester. Life Sci. 52: L245-249

43. Machelska H, Labuz D, Przewlocki R and Przewlocka B (1997) Inhibition of nitric oxide synthase enhances antinociception mediated by mu, delta and kappa opioid receptors in acute and prolonged pain in the rat spinal cord. J. Pharmacol. Exp. Ther. 282: $977-984$

44. Przewlocki R, Machelska H and Przewlocka B (1993) Inhibition of nitric oxide synthase enhances morphine antinociception in the rat spinal cord. Life Sci. 53 $\mathrm{L} 1-\mathrm{L} 5$

45. Cuellar B, Fernandez AP, Lizasoain I, Moro MA, Lorenzo P, Bentura ML, Rodrigo Jand Leza JC (2000) Up-regulation of neuronal NO synthase immunoreactivity in opiate dependence and withdrawal. Psychopharmacology (Berl). 148: 66-73

46. Deliconstantinos G, Villiotou V and Stavrides JC (1995) Met-enkephalin receptor-mediated increase of membrane fluidity modulates nitric oxide (NO) and cGMP production in ratbrain synaptosomes. Neurochem. Res. 20:217-224

47. Pataki I and Telegdy G (1998) Further evidence that nitric oxide modifies acute and chronic morphine actions in mice. Eur. J. Pharmacol. 357: 157-162

48. Kavaliers M, Choleris E, Prato FS and Ossenkopp K (1998) Evidence for the involvement of nitric oxide and nitric oxide synthase in the modulation of opioidinduced antinociception and the inhibitory effects of exposure to $60-\mathrm{Hz}$ magnetic fields in the land snail. Brain Res. 809: 50-57

49. Granados-Soto V, Rufino MO, Gomes Lopes LD and Ferreira SH (1997) Evidence for the involvement of the nitric oxide-cGMP pathway in the antinociception of morphine in the formalin test. Eur. J. Pharmacol. 340: 177 180

50. Kolesnikov YA, Pan YX, Babey AM, Jain S, Wilson R and Pasternak GW (1997) Functionally differentiating two neuronal nitric oxide synthase isoforms through antisense mapping: evidence for opposing NO actions on morphine analgesia and tolerance. Proc. Natl. Acad. Sci. USA 94: 8220-8225

51. Ding YQ, LiJL, Lu BZ, Wang D, Zhang ML and Li JS (1998) Co-localization of muopioid receptor-like immunoreactivity with substance $\mathrm{P}$-LI, calcitonin generelated peptide-LI and nitric oxide synthase- $\mathrm{LI}$ in vagal and glossopharyngeal afferent neurons of the rat. Brain Res. 792: 149-153
52. Fox-Threlkeld JE, Daniel EE, Christinck F, Hruby VJ, Cipris S and Woskowska Z (1994) Identification of mechanisms and sites of actions of mu and delta opioid receptor activation in the canine intestine. J. Pharmacol. Exp. Ther. 268: 689700

53. Menzies JR and Corbett AD (2000) Nociceptin inhibits tonic nitric oxide release in the mouse isolated proximal colon. Eur. J. Pharmacol. 388: 183-186

54. Hatzoglou A, Ouafik L, Bakogeorgou E, Thermos K and Castanas E (1995) Morphine cross-reacts with somatostatin receptor SSTR2 in the T47D human breast cancer cell line and decreases cell growth. Cancer Res. 55: 5632-5636

55. Hatzoglou A, Bakogeorgou E, Hatzoglou C, Martin PM and Castanas E (1996) Antiproliferative and receptor binding properties of alpha- and betacasomorphins in the T47D human breast cancer cell line. Eur. J. Pharmacol. 310: $217-223$

56. Hatzoglou A, Bakogeorgou E and Castanas E (1996) The antiproliferative effect of opioid receptor agonists on the T47D human breast cancer cell line, is partially mediated through opioid receptors. Eur. J. Pharmacol. 296: 199-207

57. Hatzoglou A, Kampa M and Castanas E Wine antioxidants as antiproliferative agents in human hormone-dependent tumors. In: 6th International Symposium on Grapevine physiology and biotechnology, Heraklion, Greece, 11-15 June 2000 , pp. 7

58. Munro AW, Taylor P and Walkinshaw MD (2000) Structure of redox enzymes. Curr. Opinion Biotechnol. 11: 369-376

59. Barjavel MJ and Bhargava HN (1994) Effect of opioid receptor, agonists on nitric oxide synthase activity in rat cerebral cortex homogenate. Neurosci. Lett. 181: $27-30$

60. Benyo Z, Szabo C, Velkei MH, Bohus B, Wahl M and Sandor P (1996) Intravenous beta-endorphin administration fails to alter hypothalamic blood flow in rats expressing normal or reduced nitric oxide synthase activity. Peptides 17: $733-736$

61. luvone T, Capasso A, D'Acquisto F and Carnuccio R (1995) Opioids inhibit the induction of nitric oxide synthase in $\mathrm{J} 774$ macrophages. Biochem. Biophys. Res. Commun. 212: $975-980$

62. Kowalski J (1998) Augmenting effect of opioids on nitrite production by stimulated murine macrophages. Neuropeptides 32: 287-291

63. Li X and David Clark J (2000) Chronic morphine exposure and the expression of heme oxygenase type 2. Brain Res. Mol. Brain Res. 75: 179-184

64. Lysle DT and How T (2000) Heroin modulates the expression of inducible nitric oxide synthase. Immunopharmacology 46: 181-192

65. Bhargava HN (1994) Nitric oxide synthase inhibition blocks tolerance to the analgesic action of kappa-opiate receptor agonist in the rat. Pharmacology 48: $234-241$

66. Thorat SN, Reddy PL and Bhargava HN (1993) Evidence for the role of nitric oxide in kappa-opiate tolerance in mice. Brain Res. 621: 171-174

67. Bhargava HN, Kumar S and Barjavel MJ (1998) Kinetic properties of nitric oxide synthase in cerebral cortex and cerebellum of morphine tolerant mice. Pharmacology 56: 252-256

68. Engel PC (1981) Enzyme kinetics: The steady-state approach., 2nd edition, p. 96. London: Chapman and Hall

69. Ko JL, Arvidsson U, Williams FG, Law PY, Elde R and Loh HH (1999) Visualization of time-dependent redistribution of ä-opioid receptors in neuronal cells during prolonged agonist exposure. Mol. Brain Res. 69: 171-185

70. Gaudriault G, Nouel D, Dal Farra C, Beaudet A and Vincent J-P (1997) Receptorinduced internalization of selective peptidic i and ä opioid ligands. J. Biol. Chem. 272: $2880-2888$

71. Schweigerer L, Schmidt W, Teschenmacher H and Gramsch C (1985) âendorphin: Surface binding and internalization in thymoma cells. Proc. Natl. Acad. Sci. USA. 82: 5751-5755

72. Law PY, Hom DS and Loh HH (1984) Down regulation of opiate receptor in neuroblastoma x glioma NG108-15 hybrid cells. J. Biol. Chem. 259: 4096-4104

73. Li J-G, Luo L-Y, Krupnick JG, Benovic JL and Liu-Chen L-Y (1999) U50, 488H induced internalization of the human ê opioid receptor involves a â-arestin- and dynamin-dependent mechanism: ê receptor internalization is not required for mitogen-activated protein kinase activation. J. Biol. Chem. 274: 12087-12094

74. Jordan BA, Cvejic S and Devi LA (2000) Kappa opioid receptor endocytosis by dynorphin peptides. DNA Cell. Biol. 19: 19-27

75. Li J-G, Benovic JL and Liu-Chen L-Y (2000) Mechanisms of agonist-induced down-regulation of the human ê-opioid receptor: Internalization is required for down regulation. Mol. Pharmacol. 58: 795-801 
76. Maneckjee R, Biswas R and Vonderhaar BK (1990) Binding of opioids to human MCF-7 breast cancer cells and their effects on growth. Cancer Res. 50: $2234-$ 2238

77. Grisham MB, Johnson GG and Lancaster JRJ (1996) Quantitation of nitrate and nitrite in extracellular fluids. Meth. Enzymol. 268: 237-246

78. Granger DL, Taintor RR, Boockvar KS and Hibbs JBJ (1996) Measurement of nitrate and nitrite in biological samples using nitrate reductase and Griess reaction. Meth. Enzymol. 268: 142-151

79. Kopec KK and Carroll RT (2000) Phagocytosis is regulated by Nitric Oxide in Murine Microglia. Nitric Oxide Biol. Med. 4: 103-111

80. Kojima H, Nakatsubo N, Kikuchi K, Kawahara S, Kirino Y, Nagoshi H, Hirata Y and Nagano T (1998) Detection and imaging of nitric oxide with novel fluorescent indicators: Diaminofluorosceins. Anal. Chem. 70, 2446-2453 of the constitutive endothelial nitric oxide synthase gene in Alzheimer disease. Mol. Chem. Neuropathol. 30: 139-159
81. Marletta MA (1993) Nitric oxide synthase structure and mechanism. J. Biol. Chem. 268: $12231-12234$

82. Moncada S and Higgs A (1993) The L-arginine-nitric oxide pathway. N. Engl. J. Med. 329: 2002-2012

83. Dawes EA (1972) Quantitative problems in biochemistry. 1st edition. Edinburgh: Churchill Livingstone 